\title{
REASONABLE FORESEEABILITY OF HARM AS AN ELEMENT OF NUISANCE
}

\section{Maria Hook*}

A landowner's utility pipe bursts and floods the plaintiff's land. It was reasonably foreseeable that the water would cause flood damage to the plaintiff's land in case of an escape. But it was not reasonably foreseeable that the pipe would burst and, hence, that there would be an escape of water. Can the landowner be liable in nuisance? This paper explores the conceptual implications of the proposition that reasonable foreseeability of harm is an element of liability in nuisance. It argues that, if reasonable foreseeability of harm is an element of nuisance, then nuisance can no longer be thought of as a strict liability tort.

\section{INTRODUCTION}

$\mathrm{D}$, a construction company, carries out redevelopment works that require the sinking of a large number of concrete piles. Before D starts on the project, it undertakes an extensive investigation of ground conditions and concludes that there are no underground obstructions that will be affected by the works. This conclusion turns out to be wrong. When D pours concrete into the shafts, the concrete seeps through a private sewer into the public sewerage system, owned and operated by $\mathrm{P}$, and causes a partial blockage. Would $\mathrm{P}$ succeed in a claim of private nuisance, even if $\mathrm{D}$ could not have reasonably foreseen the escape of the concrete from its site?

The Court of Appeal of England and Wales recently decided this question, without much fanfare, in D's favour in Northumbrian Water Ltd $v$ Sir Robert McAlpine Ltd. ${ }^{1}$ A defendant will not be liable in nuisance for an interference with the plaintiff's land that was not reasonably foreseeable (see Part II). This article argues that the Court's conclusion is much more significant than the Court may have realised. It goes to the very core of the tort of nuisance. If reasonable foreseeability of harm is an element of nuisance, the function of the tort is to impose liability for wrongful conduct as opposed to wrongful damage (see Part III), and it overlaps almost entirely with negligence in cases of physical damage (see Part IV). Put bluntly, if reasonable foreseeability of harm is an element of

* Lecturer, University of Otago, maria.hook@otago.ac.nz.

1 Northumbrian Water Ltd v Sir Robert McAlpine Ltd [2014] EWCA Civ 685, [2014] Env LR 28. 
nuisance, it is not a strict liability tort at all. It is a tort that resolves competing interests in the use of land by regulating the defendant's conduct.

\section{REASONABLE FORESEEABILITY OF INTERFERENCE WITH PLAINTIFF'S LAND}

This article argues that the decision in Northumbrian Water Ltd signifies the end of nuisance as a strict liability tort. In order to make this point good, it is first necessary to unravel the genesis of the Court of Appeal's decision. The Court rejected the nuisance claim because the escape of concrete from the building site into a public sewer was unforeseeable. ${ }^{2}$ In doing so, the Court relied on an obiter dictum by Lord Hoffmann in Transco plc v Stockport Metropolitan Borough Council that nuisance requires an intentional or foreseeable interference with land. ${ }^{3}$ But the role of foreseeability in nuisance has been much more confused than the Court of Appeal or Lord Hoffmann let on. Courts have produced a range of conflicting dicta; ${ }^{4}$ and scholars, to the extent that they have expressed a view, are divided on the matter. ${ }^{5}$

One of the reasons for this confusion is that courts have distinguished - but not always clearly between foreseeability of harm and foreseeability of the type of harm. ${ }^{6}$ The distinction dates back to Blackburn J's judgment in Rylands $v$ Fletcher, where he spoke of "anything likely to do mischief if it escapes", ${ }^{7}$ and of the defendant's liability to "answer for the natural and anticipated consequences" of such a hypothetical escape. ${ }^{8}$ This distinction has been retained in the context of Rylands $v$ Fletcher ever since. ${ }^{9}$

2 At [19].

3 At [17] referring to Transco plc v Stockport Metropolitan Borough Council [2003] UKHL 61, [2004] 2 AC 1 at [26]-[27] per Lord Hoffmann.

4 See for example Halsey v Esso Petroleum Ltd [1961] 1 WLR 683 (QB) at 691: "So far as the present case is concerned, liability for nuisance by harmful deposits could be established by proving damage by the deposits to the property in question, provided of course that the injury was not merely trivial. Negligence is not an ingredient of the cause of action ..."; and Transco, above n 3, at [97] per Lord Walker: "negligence (in the sense of a demonstrable failure to take reasonable care) has traditionally been regarded as irrelevant".

5 See for example Gerry Cross "Does Only the Careless Polluter Pay? A Fresh Examination of the Nature of Private Nuisance" (1995) 111 LQR 445 at 458-473 and the references there cited.

6 See David Wilkinson "Cambridge Water Company v Eastern Counties Leather plc: Diluting Liability for Continuing Escapes" (1994) 57 MLR 799 at 804-805.

$7 \quad$ Rylands v Fletcher (1866) LR 1 Ex 265 (Exch Ch) at 279 (emphasis added).

8 At 280

9 Cambridge Water Co Ltd v Eastern Counties Leather plc [1994] 2 AC 264 (HL). See also Donal Nolan "The Distinctiveness of Rylands v Fletcher" (2005) 121 LQR 421 at 444. 
There is no doubt that nuisance, like Rylands $v$ Fletcher, requires reasonable foreseeability of the type of harm: ${ }^{10}$ it must have been reasonably foreseeable that, in case of an escape or interference with P's land (that is, in case of the concrete escaping from D's site), there would be damage, and the damage would be of the same type that now affects P's land (that is, blockage of P's sewers). But reasonable foreseeability of the type of harm, although it suggests constructive knowledge of the potential for harm, ${ }^{11}$ does not imply reasonable foreseeability of the escape itself: it does not imply reasonable foreseeability of harm occurring. So, to succeed in a claim of nuisance, does $\mathrm{P}$ have to show that the escape of concrete was reasonably foreseeable?

\section{$A$ The Wagon Mound (No 2)}

A case that is often cited as authority for a requirement of foreseeability is Overseas Tankship (UK) Ltd $v$ The Miller Steamship Co Pty (The Wagon Mound (No 2)). ${ }^{12}$ In that case, a large amount of oil overflowed from the Wagon Mound into the sea and caught fire when, as a result of welding repairs to the plaintiffs' vessels, pieces of hot metal fell into the sea and made contact with the oil. The fire caused extensive damage to the plaintiffs' vessels, who then sought damages from the charterer of the Wagon Mound in public nuisance and negligence. The defendant argued that fire damage to the vessels was not reasonably foreseeable. The Privy Council rejected that argument, with the result that the defendant was liable in negligence and nuisance.

But the Privy Council also dealt with the plaintiffs' alternative argument that foreseeability did not form part of determining damages in nuisance. The plaintiffs submitted that foreseeability was part of determining the amount of damages in negligence, because in negligence foreseeability was also part of determining liability. In nuisance, on other hand, foreseeability was not part of determining liability, so it should not form part of determining the amount of damages. ${ }^{13}$

Lord Reid agreed that it was "quite true that negligence is not an essential element in nuisance", because "[n]uisance is a term used to cover a wide variety of tortious acts or omissions and in many negligence in the narrow sense is not essential". ${ }^{14}$ In the present class of public nuisance - creating a danger to persons or property in navigable waters - it was admitted that fault was essential, so here foreseeability was, in fact, an essential element in determining liability. In these circumstances, it would be wrong: ${ }^{15}$

10 Overseas Tankship (UK) Ltd v Miller SS Co Pty [1967] 1 AC 617 (PC) [The Wagon Mound (No 2)].

11 Compare Transco, above n 3, at [64] per Lord Hobhouse.

12 The Wagon Mound (No 2), above n 10, cited by for example Lord Hoffmann in Transco, above n 3, at [26].

13 The Wagon Mound (No 2), above n 10, at 639.

14 At 639

15 At 640 
... to discriminate between different cases of nuisance so as to make foreseeability a necessary element in determining damages in those cases where it is a necessary element in determining liability, but not in others.

Foreseeability was a necessary element in determining damages in all cases of nuisance, whether or not it was also a necessary element in determining liability.

It is difficult to construe Lord Reid's reasoning as authority for a general requirement of foreseeability in private nuisance. His Lordship seemed to be primarily concerned with remoteness of damage, or foreseeability of the type of damage. In fact, Lord Reid emphasised that liability in nuisance did not always depend on foreseeability.

\section{$B$ Cambridge Water Co v Eastern Counties Leather plc}

This was also the interpretation adopted by the House of Lords in Cambridge Water Co $v$ Eastern Counties Leather plc, ${ }^{16}$ where Lord Goff relied on The Wagon Mound (No 2) to hold that liability in Rylands $v$ Fletcher required foreseeability of the type of harm. The defendant, Eastern Counties Leather (ECL), used a chlorinated solvent to degrease pelts at its tannery. The solvent seeped into the ground below ECL's premises and travelled in percolating water to the plaintiff's borehole, contaminating the water supply. The plaintiff brought an action for damages in negligence, nuisance and the rule in Rylands $v$ Fletcher - but only the latter was on appeal before the House of Lords. The trial Judge had found that ECL could not reasonably have foreseen that the repeated spillages of solvent would enter the aquifer, that detectable quantities would be found down-catchment, or that the spillages would produce water contamination. In fact, any spillage would have been expected to evaporate in the air. ${ }^{17}$

ECL submitted that strict liability under the rule in Rylands $v$ Fletcher arises only where the defendant reasonably ought to have foreseen that the things the defendant collected on their land would cause damage of the relevant kind if they escaped. Lord Goff considered that there was a close relationship between nuisance and the rule in Rylands $v$ Fletcher, so it was helpful to inquire first "whether foreseeability of such damage is an essential element in the law of nuisance". ${ }^{18}$ His Lordship thought that it was, because reasonable foreseeability of the relevant type of damage had long been a part of negligence, and because The Wagon Mound (No 2) seemed to support that conclusion: ${ }^{19}$

16 Cambridge Water, above n 9.

17 At 292.

18 At 297.

19 At 301 and 304. 
It is widely accepted that this conclusion, although not essential to the decision of the particular case, has nevertheless settled the law to the effect that foreseeability of harm is indeed a prerequisite of the recovery of damages in private nuisance, as in the case of public nuisance. ... It is unnecessary in the present case to consider the precise nature of this principle; but it appears from Lord Reid's statement of the law that he regarded it essentially as one relating to remoteness of damage.

Accordingly since, following the observations of Lord Reid ... the recovery of damages in private nuisance depends on foreseeability by the defendant of the relevant type of damage, it would appear logical to extend the same requirement to liability under the rule in Rylands $v$ Fletcher.

It followed that ECL could not be liable under the rule, because ECL could not reasonably have foreseen that the solvent would cause water contamination at the plaintiff's borehole when it brought the solvent on its land and used it in the tanning process. What Lord Goff did not conclude was that liability under the rule depended on reasonable foreseeability of harm occurring, that is, a reasonably foreseeable escape. A defendant under the rule is strictly liable to the extent that they could reasonably foresee that an escape - however unlikely an escape might be - would result in the relevant damage.

In these circumstances, neither Cambridge Water nor The Wagon Mound (No 2) provides any real authority for reasonable foreseeability of harm as an element of nuisance. In fact, Lord Goff's speech would seem to provide support for the opposite conclusion. His Lordship seemed to agree with the view, expressed by Professor Newark, that the rule in Rylands $v$ Fletcher was nothing more than an extension of nuisance to one-off escapes. ${ }^{20} \mathrm{He}$ also pointed out that the escape of the solvent had not been an isolated but a continuing escape, and concluded that it would be "strange" if liability in this case should "be rendered more strict" by "characterising the case as one falling under the rule in Rylands v Fletcher" rather than nuisance. ${ }^{21}$ In other words, nuisance and the rule in Rylands $v$ Fletcher are equally strict. A logical inference from this conclusion would seem to be that nuisance, like Rylands $v$ Fletcher, does not require a reasonably foreseeable escape.

\section{Hamilton v Papakura District Council}

The New Zealand Court of Appeal had occasion to consider the role of foreseeability in Hamilton v Papakura District Council, ${ }^{22}$ but failed to provide much clarity on the matter. The plaintiffs in that case claimed that the water supplied by the Papakura District Council had poisoned their hydroponically grown tomato plants. They alleged that the water was contaminated with

20 At 304. See FH Newark "The Boundaries of Nuisance" (1949) 65 LQR 480.

21 Cambridge Water, above n 9, at 306.

22 Hamilton v Papakura District Council [2000] 1 NZLR 265 (CA). 
herbicide residues toxic to the plants because Watercare, the second defendant, had used weed spray in the catchment area.

Gault $\mathbf{J}$, in his judgment delivered for the Court, noted that liability in nuisance was "strict". ${ }^{23}$ Relying on Cambridge Water, his Honour considered that: ${ }^{24}$

... once it has been shown that the damage was foreseeable, it is irrelevant that the actual act causing the damage was not the fault of the defendant, or that the defendant acted with reasonable skill and care.

In fact, here the issue was not whether the escape of weed spray into the water supply had been reasonably foreseeable, but whether the type of damage was reasonably foreseeable: ${ }^{25}$

The test is whether, when it carried out the weed spraying on its catchment land in the manner it did, Watercare could have foreseen that after run-off into the water storage reservoir with its consequent dilution the town water would have proved toxic to plants sensitive to contamination levels at or below $10 \mathrm{ppb}$.

His Honour concluded that the defendants were not liable because Watercare could not have foreseen that the herbicide would damage the plaintiffs' sensitive tomatoes. The decision was upheld on appeal by the Privy Council. ${ }^{26}$

The case does not squarely address the question that is the subject of this article, which is whether the escape - as opposed to the type of damage in the case of an escape - has to be reasonably foreseeable. Gault J's dictum, cited above, that "it is irrelevant ... that the defendant acted with reasonable skill and care" would suggest that the answer is no. ${ }^{27} \mathrm{In}$ an apparent selfcontradiction, his Honour also considered that a defendant could raise as a defence to a claim in nuisance "that he was exercising reasonable skill and care in the ordinary and natural use of land". ${ }^{28}$ Perhaps this statement may simply be construed to mean that such a defendant cannot be liable in nuisance because there was no unreasonable interference with the plaintiff's use or enjoyment of land (that is, there was an "ordinary and natural use of land"). ${ }^{29}$ In any case, the better view is that the Court of Appeal purported to adopt Lord Goff's reasoning in Cambridge Water, which seems to

23 At [74].

24 At [76].

25 At [77].

26 Hamilton v Papakura District Council [2002] 3 NZLR 308 (PC).

27 Hamilton, above $\mathrm{n} 22$, at [76]. For an alternative meaning of "reasonable skill and care" that is not linked to foreseeability, see Part III:C below.

28 At [74].

29 Compare $\mathrm{n} 34$ below. But it is not obvious why this should be a defence rather than an element of liability. 
support the proposition that nuisance does not require a reasonably foreseeable escape (see Part B, above).

\section{$D$ Transco plc v Stockport Metropolitan Borough Council}

Yet Lord Hoffmann in Transco plc v Stockport Metropolitan Borough Council offered an alternative interpretation of Lord Goff's reasoning. ${ }^{30}$ The case involved a leaking pipe that supplied a multi-storey block of flats with water. The failure of the pipe went undetected for a considerable period. As a result, a large quantity of water percolated into an embankment, causing it to collapse. The embankment supported the plaintiff's high-pressure gas main, and the plaintiff was required to take remedial action. It sought to recover the cost of repair under the rule in Rylands $v$ Fletcher. The House of Lords took the opportunity to consider whether the rule in Rylands v Fletcher still served a useful purpose. But only Lord Hoffmann considered directly the strictness of liability in nuisance.

Speaking obiter, his Lordship expressed the view that nuisance requires an intended or reasonably foreseeable escape, citing The Wagon Mound (No 2) as authority: ${ }^{31}$

But a conclusion that an occupier of land has no right to discharge water or filth ... or chemicals ... upon his neighbour's land is not inconsistent with a rule that he will be liable in damages only for damage caused by a discharge which was intended or foreseeable. Indeed, that is the general rule of liability for nuisance today ...

Lord Hoffmann then went on to explain that this was, in fact, what Lord Goff had meant when he said that the rule in Rylands $v$ Fletcher was an extension of the law of nuisance to one-off escapes: ${ }^{32}$

Rylands $v$ Fletcher was therefore an innovation in being the first clear imposition of liability for damage caused by an escape which was not alleged to be either intended or reasonably foreseeable. I think that this is what Professor Newark meant when he said in his celebrated article ... that the novelty in Rylands $v$ Fletcher was the decision that an "isolated escape is actionable". That is not because a single deluge is less of a nuisance than a steady trickle, but because repeated escapes ... do not raise any question about whether the escape was reasonably foreseeable.

Lord Goff of Chieveley, in a speech which repays close attention, took the rule back to its origins in the law of nuisance and said that liability should be no more extensive than it would have been in nuisance if the discharge itself had been negligent or intentional. Adopting the opinion of Professor Newark, to

30 Transco, above $\mathrm{n} 3$, at [33] and [27].

31 At [26].

32 At [26]-[27] and [33]. Compare the link drawn by Donal Nolan between the element of continuity and intention/carelessness: Nolan, above n 9, at 437-438. 
which I have already referred, he said that the novel feature of Rylands $v$ Fletcher was to create liability

for an "isolated" (ie. unforeseeable) escape.

Lord Hoffmann's reasoning has many benefits. It sets an end to the arbitrary and often difficult rule that a nuisance consist of an ongoing or repeated interference, or that it at least be the result of an ongoing state of affairs. ${ }^{33}$ If "ongoing" or "continuing" is code for "reasonably foreseeable" because a defendant would, or should, have been aware of repeated escapes - then even a reasonably foreseeable but isolated escape might found liability in nuisance. Lord Hoffmann's solution is also more consistent with the modern role of Rylands v Fletcher. Why should it be so difficult to establish non-natural use under the rule in Rylands $v$ Fletcher, if the law of nuisance makes do without such a limitation and imposes liability for physical damage as long as there is some form of continuing state of affairs? ${ }^{34}$ Put another way, why should nuisance be just as strict as the rule in Rylands $v$ Fletcher, when even the rule in Rylands $v$ Fletcher implicitly "carries on the negligence idea that the requisite degree of care is proportionate to the magnitude of the risk"? ${ }^{35}$

But despite these benefits, Lord Hoffmann's approach suffers from an obvious flaw, which is that an isolated escape is not necessarily unforeseeable, and an ongoing escape is not necessarily foreseeable. Cambridge Water itself is a perfect illustration of this. ECL could not reasonably have foreseen that the repeated spillages would enter the aquifer or that detectable quantities of the solvent would be found down-catchment. In these circumstances, it is doubtful that Lord Goff meant to equate "isolated escape" with "unintended or unforeseeable escape". Neither Cambridge Water nor The Wagon Mound (No 2) provide direct support that nuisance requires reasonably foreseeable harm. Prior to the decision in Northumbrian Water, this question appeared to be unsettled. ${ }^{36}$

33 On the difficult requirement of continuity generally see John Murphy The Law of Nuisance (Oxford University Press, Oxford, 2010) at [1.19]-[1.24]. The rule does have value insofar as non-physical interferences are concerned because an isolated interference with the amenity of the plaintiff's land will rarely be unreasonable: at [2.18].

34 But note the tendency to assimilate the concepts of non-natural use and reasonable user, based on dicta in Cambridge Water, above n 9, at 299. See for example Arscott v The Coal Authority [2004] EWCA Civ 892, [2005] Env LR 6 at [26]-[28]. Compare Barr v Biffa Waste Services Ltd [2012] EWCA Civ 312, [2013] QB 455 .

35 Ernest Weinrib The Idea of Private Law (Harvard University Press, Cambridge, Massachusetts, 1995) at 189 as cited in John Murphy "Rethinking Injunctions in Tort Law" (2007) 27 OJLS 509 at n 68.

36 Most cases that are cited in support of a requirement of reasonably foreseeable harm tend to fall into one of two categories. Either they are cases where the court relied on reasonable foreseeability of the type of damage (Savage v Fairclough [2000] Env LR 183 (CA); and Bybrook Barn Garden Centre v Kent City Council [2001] Env LR 30 (CA) at [33] to the extent that reasonable foreseeability of the type of damage also requires foreseeability of the potential risk), or where the court failed to distinguish between the two types of foreseeability (Arscott $v$ The Coal Authority, above n 34, at [30]). Alternatively, they are cases where the defendant did not create the nuisance: Delaware Mansions Ltd $v$ Westminster City Council [2002] 1 AC 321 (HL); Marcic v Thames Water Utilities Ltd [2002] EWCA Civ 64, [2002] QB 929 at [85] (reversed on appeal on different points of law). Compare Ilford Urban District Council v Beal [1925] 1 KB 


\section{E Northumbrian Water Ltd v Sir Robert McAlpine Ltd}

It is in this context, then, that the judgment in Northumbrian Water should be read. During the defendant's development works, concrete escaped into a private sewer and led to a blockage of the plaintiff's sewerage system. The defendant had been unaware of the existence of the private sewer, and hence was unaware that there was a risk of the concrete escaping into the plaintiff's sewer. The plaintiff brought claims in negligence and nuisance. Both claims failed. The defendant had not been negligent because it could not reasonably have foreseen that the concrete would escape beyond the borders of the site. ${ }^{37}$ It had taken reasonable care in investigating the existence of underground structures.

In support of its claim in nuisance, the plaintiff submitted that the escape of concrete was not an isolated event, because it occurred as part of continuing construction operations; and that, in these circumstances, nothing more than physical damage to the sewer was required to make the defendant liable. But if fault was an element of the claim, then the element was satisfied because the defendant accepted that piling operations of this kind created a risk of concrete escaping into voids in the ground. ${ }^{38}$ The Court of Appeal rejected these submissions. Relying on the speeches of Lord Goff in Cambridge Water and Lord Hoffmann in Transco, the Court held that the absence of negligence proved fatal to the claim: ${ }^{39}$

... there was no evidence to suggest that constructing concrete piles by the method adopted in this case was unusual or liable to create problems for neighbouring landowners. The respondent, or at any rate those for whose actions it was responsible, were aware that concrete can leak out of shafts drilled to create piles into surrounding voids in the sub-soil, but there is no reason to think that the respondent should for that reason have foreseen the possibility that concrete might escape the confines of the site and find its way onto neighbouring land. Indeed, had it not been for the disused drain, there is no reason to think that it would have done so.

There was no general rule imposing strict liability in cases of physical damage. Nuisance required fault, in the form of foreseeability of an escape. Here, the defendant "was not negligent in failing to discover the existence of the drain", and so "the escape of concrete into the appellant's sewer was not reasonably foreseeable". 40

671. In such cases, negligence is a well-established element of the claim: Sedleigh-Denfield v O'Callaghan [1940] AC 880 (HL); and Goldman v Hargrave [1967] 1 AC 645 (PC).

37 Northumbrian Water, above $\mathrm{n}$ 1, at [9].

38 At [10].

39 At [19].

40 At [19]. 


\section{CULPA, NOT CAUSA}

Nuisance is traditionally associated with the principle of strict liability. ${ }^{41}$ The conventional meaning of strict liability, in this context, is coextensive with liability regardless of fault or negligence. The defendant is liable because they caused the relevant interference with the plaintiff's land, and it is immaterial whether they intended to bring about the interference or whether they were negligent in causing it, or whether they should not have done what they did to cause it. If the Court of Appeal is right that reasonable foreseeability of harm is a general element of nuisance, then nuisance is no longer a strict liability tort. It is fault-based - a tort about wrongful conduct - because the element of foreseeability requires the defendant to comply with a particular standard of care.

\section{A Strict Liability}

In the law of torts, the most common meaning of strict liability is liability in the absence of fault or negligence. A defendant who has created a nuisance is often said to be strictly liable, in contrast to a defendant who has merely continued a nuisance, who will not be liable unless the failure to stop the nuisance was negligent. ${ }^{42}$ In this sense, a defendant is strictly liable on the basis that they caused the harm, regardless of whether or not they were reasonably able to prevent it. ${ }^{43}$ It is the harm that is wrongful, not the conduct. The underlying rationale is simple: strict liability transfers the burden of harm from the victim to the person who created it. ${ }^{44}$

The classic example of this type of strict liability is still the rule in Rylands $v$ Fletcher. A defendant who operates a reservoir that bursts and floods the plaintiff's land is held liable on the basis that they undertook a risky activity and caused the flooding. The court need not find, in order to impose liability, that the defendant should not have operated the reservoir in the manner they did. ${ }^{45}$ It is true that the strictness of the liability is significantly softened by the various elements of the rule: the defendant must have reasonably foreseen the type of damage, which goes hand in hand with a reasonable appreciation that the activity is at least capable of causing harm; and the

41 Cambridge Water, above n 9, at 299: "liability for nuisance has generally been regarded as strict". In relation to the natural right of support to land see Brouwers $v$ Street [2010] NZCA 463, [2011] 1 NZLR 645 at [70]; and Street v Brouwers [2011] NZSC 17 at [4]. See also Halsey v Esso Petroleum Ltd, above n 4; Paxhaven Holdings Ltd v Attorney-General [1974] 2 NZLR 185 (SC) at 188; and Midwood \& Co Ltd v Manchester Corp [1905] 2 KB 597 (CA). But see John Eekelaar "Nuisance and Strict Liability" (1973) 8 Irish Jurist 191.

42 See for example Cambridge Water, above n 9, at 300.

43 See Allan Beever The Law of Private Nuisance (Hart Publishing, Oxford, 2013) at 99. But see Eekelaar, above $\mathrm{n} 41$.

44 See Transco, above n 3, at [55] per Lord Hobhouse: "The principle which the rule [in Rylands $v$ Fletcher] reflects is also easily apparent. It is that the law of private nuisance recognises that the risk must be borne by the person responsible for creating it and failing to control it."

45 Roderick Bagshaw "Rylands Confined" (2004) 120 LQR 388 at 388-389; and Nolan, above n 9, at 430. 
defendant's use of the land must have been non-natural. But the particular activity or use need not have been wrongful. It is entirely permissible to engage in a potentially harmful use of land.

\section{B Foreseeability and Wrongful Conduct}

If the Court of Appeal is right that reasonable foreseeability of harm is a general element of nuisance, then nuisance can no longer be said to be a strict liability tort. It is concerned with wrongful conduct. Unlike the rule in Rylands $v$ Fletcher, which treats as irrelevant the permissibility (or non-permissibility) of the conduct that caused the damage, it does not attribute liability on the basis of causation alone. In Northumbrian Water, the defendant would have been liable in nuisance if the Court had been able to conclude that it should not have poured the concrete into the shafts - it was not enough that the defendant had caused the blockage of the sewer.

How does a requirement of reasonable foreseeability of harm turn nuisance into a fault- rather than cause-based tort? The law creates a link between foreseeability of harm and wrongful conduct by subjecting the defendant's actions to a standard of care. In other words, foreseeability of harm is not an end in itself; it is relevant only to the extent that the harm was reasonably preventable. ${ }^{46} \mathrm{In}$ Northumbrian Water, the defendant's piling works carried a foreseeable risk of harm that was sufficient to create a duty of care, but the defendant was not liable for the damage caused by its escaping concrete. It had done everything it reasonably could to prevent the damage. The missing element in the plaintiff's claim was a failure to live up to the requisite standard of care that would have been expected of a reasonable person in the defendant's circumstances. It was not enough that the defendant had created a risk of harm, which then happened to eventuate.

In fact, the meaning of reasonable foreseeability of harm would be difficult to gauge if it were divorced from the defendant's conduct (in other words, if nuisance required only foreseeability of harm, without an attendant failure to live up to a standard of care) ${ }^{47}$ If the element was satisfied by a theoretical risk of escape, then it would add nothing to the requirement that the type of damage be reasonably foreseeable. A defendant who should have reasonably foreseen that the concrete would damage sewers if it escaped must have been able to appreciate that there was at least a theoretical risk of escape. On the other hand, if more than a theoretical risk of escape were needed, it would surely be necessary to balance the likelihood of an escape with the gravity of the potential harm - an exercise that comes close to the imposition of a standard of care.

\section{The Defendant's Reasonableness Beyond Foreseeability}

The Court of Appeal's requirement of reasonably foreseeable harm turns nuisance into a tort about wrongful conduct. Its purpose is to regulate activities that cause an undue interference with

46 See Beever, above n 43, at 99 and 105.

47 At 100-104. But compare Christian Witting Street on Torts (14th ed, Oxford University Press, Oxford, 2015 ) at 460. 
the plaintiff's interests in land. But is this description of the tort consistent with the principles of nuisance more generally? How does it sit with cases where foreseeability is not in issue, and where the question in dispute is whether the interference is sufficiently grave to warrant liability?

This question does not arise where the defendant causes physical damage to the plaintiff's land, which will always amount to an unreasonable interference provided the damage is not trivial. ${ }^{48}$ But it is likely to be the main issue where the defendant interferes with the amenity value of the land. Courts undertake a balancing exercise to determine this issue, weighing "the right of the occupier to do what he likes with his own" with "the right of his neighbour not to be interfered with". ${ }^{49}$ The plaintiff can be expected to tolerate some interference with their use or enjoyment of land, so courts must weigh all relevant circumstances to conclude whether the interference was ultimately unreasonable.

This mantra of "give and take, live and let live", ${ }^{50}$ to the extent that it prescribes a standard of conduct amongst neighbours, is consistent with the tort's focus on the wrongfulness of the defendant's activities. The tort enables the defendant to claim that they were entitled to use their land in the offending manner, despite the harm caused to the plaintiff's interests - not because the harm was unforeseeable, but because the plaintiff could be expected to put up with it. For the nuisance claim to succeed, the court must find that the defendant wrongly prioritised their interests over those of the plaintiff, and that they should not have used their land in the offending manner. A defendant's conduct is wrongful if they knowingly (or negligently) operate a factory in a manner that causes excessive smells, in the same way that their conduct would be wrongful if they knowingly (or negligently) operated a car in a manner that causes harm to other road users. ${ }^{51}$

But in this context, too, courts have made comments that are difficult to reconcile with the view that nuisance is about wrongful conduct. In particular, it is often said that it is no defence to a claim in nuisance that the defendant has taken all reasonable care; ${ }^{52}$ and scholars frequently emphasise that it is the interference that must be unreasonable, not the defendant's conduct. ${ }^{53}$ Reasonableness

48 St Helen's Smelting Co v Tipping (1865) 11 HLC 642, 11 ER 1483 (HL).

49 Sedleigh-Denfield, above n 36, at 903 per Lord Wright.

50 Bamford $v$ Turnley (1862) $3 \mathrm{~B} \& \mathrm{~S} 66(\mathrm{~KB})$ at 84.

51 But compare Beever, above n 43, at 12 and 106. Beever argues, at 13, that "[t]he wrongfulness cannot be found in the defendant's behaviour taken in isolation" because, at 12, "[t]here is nothing wrong with operating a smelting works, an oil depot or a brick-making business".

52 Rapier v London Tramways [1893] 2 Ch 588 at 560: "If I am sued for nuisance, and the nuisance is proved, it is no defence on my part to say, and to prove, that I have taken all reasonable care to prevent it"; and Pwllbach Colliery Co Ltd v Woodman [1915] AC 634 (HL) at 638: "Their duty to their neighbour is not merely to take care so as to avoid causing a nuisance. Their duty is to abstain from causing one at all".

53 See for example Witting, above n 47, at 454. 
in this context has nothing to do with the foreseeability of harm but refers to the nature of the defendant's activity and the manner in which it is carried out. If reasonable conduct can lead to liability in nuisance, then how could it be true that the tort is about wrongful conduct? The contradiction is more apparent than real. What the courts seem to be saying is that liability in nuisance does not depend on moral culpability, and that even an activity that is performed in a manner so as to minimise the nuisance may still cause an unreasonable interference. Wrongful conduct requires neither moral blame nor an activity that is performed with lack of care. ${ }^{54}$

For example, a military airbase schedules its training flights so as to minimise noise disturbance for residents. It has done everything it could to minimise the noise short of closing down the base its conduct has been perfectly reasonable. ${ }^{55}$ But the noise is still excessive and amounts to a nuisance. Reasonableness, in that sense, is not inconsistent with wrongful conduct. ${ }^{56}$ It is a relevant - but not determinative - consideration when balancing the parties' rights. Nuisance will accord less protection to the defendant's interests if the defendant could have taken simple measures to reduce the interference ${ }^{57}$ and it will accord more protection to the defendant if they have taken such measures (that is, if they have acted reasonably). Either way, the interference with the plaintiff's land may outweigh the defendant's interest in undertaking the activity, with the result that the defendant would be wrong to prioritise their interests over those of the plaintiff - even if they do it reasonably. In the words of Lord Hoffmann, if the activity "cannot be done without causing an unreasonable interference, it cannot be done at all". 58

Confusingly, this principle (that reasonableness is no defence) is still sometimes described as a principle of strict liability. Lord Hoffmann himself said: ${ }^{59}$

Liability in nuisance is strict in the sense that one has no right to carry on an activity which unreasonably interferes with a neighbour's use of land merely because one is doing it with all reasonable care.

But the same could be said of liability in negligence, which would never be considered a strict liability tort. If the defendant cannot operate a factory without causing personal injury to the plaintiff, then they cannot operate the factory at all. It is immaterial that the defendant minimised the harmful emissions as much as possible. To say that the defendant is strictly liable because they have

54 But compare Beever, above n 43, at 106

55 Compare Dennis v Ministry of Defence [2003] EWHC 793, [2003] Env LR 34.

56 Northumbrian Water, above n 1, at [23]-[24].

57 Southwark London Borough Council v Mills [2001] 1 AC 1 (HL) at 16; and Andreae v Selfridge \& Co Ltd [1938] Ch 1 (CA) at 9-10.

58 Transco, above $\mathrm{n} 3$, at [26].

59 At [26]. 
no right to operate a polluting factory adds nothing to our understanding of the tort of negligence or, for that matter, the tort of nuisance.

\section{RESIDUAL RELEVANCE OF NUISANCE IN CASES OF PHYSICAL DAMAGE}

If nuisance is not a strict liability tort, it may, once more, be time to question whether nuisance still serves any real purpose in cases of physical damage, ${ }^{60}$ or whether plaintiffs would be better off relying on an action in negligence. If $\mathrm{D}$ knows that its piling works give rise to a risk of an escape of concrete, and if $\mathrm{D}$ fails to take reasonable measures to ensure the risk does not eventuate, then $\mathrm{D}$ will be liable in negligence and in nuisance for any reasonably foreseeable damage caused by an escape of concrete. It makes no difference if the reasoning process is framed in the language of negligence or nuisance. If $\mathrm{D}$ created an unreasonable interference with P's land in the form of physical damage, then $\mathrm{D}$ also owed a duty of care to $\mathrm{P}$ and breached it, because an interference with P's land in the form of physical damage is only unreasonable if it was caused negligently. ${ }^{61}$

Yet there may still be cases of physical damage where plaintiffs derive some benefit from the law of nuisance that would not be available to them under the law of negligence. In particular, there are three possible reasons why a plaintiff may want to rely on nuisance rather than negligence where the defendant has caused physical damage to the plaintiff's land.

First, nuisance may offer a more favourable burden of proof. In Southport Corporation v Esso Petroleum Ltd, Lord Denning had this to say in relation to claims in public nuisance: ${ }^{62}$

One of the principal differences between an action for a public nuisance and an action for negligence is the burden of proof. In an action for a public nuisance, once the nuisance is proved and the defendant is shown to have caused it, then the legal burden is shifted on to the defendant to justify or excuse himself. If he fails to do so, he is held liable, whereas in an action for negligence the legal burden in most cases remains throughout on the plaintiff. ... If the matter is left evenly in the balance, the plaintiff fails.

The same reasoning - that it is not for the plaintiff to prove negligence but for the defendant to prove an absence of negligence - has been said to apply to private nuisance. ${ }^{63}$ But neither Lord

60 See in particular Conor Gearty "The Place of Private Nuisance in a Modern Law of Torts" (1989) 48 CLJ 214.

61 See also Marcic v Thames Water Utilities Ltd, above n 36, at [55]: "Where a claim is based on damage caused by the act of an occupier of land, he is likely to be held to have used his land unreasonably if it was reasonably foreseeable that his act would harm his neighbour's land. In such circumstances, the test of liability in nuisance and negligence overlaps to the extent that the two can become indistinguishable".

62 Southport Corp v Esso Petroleum Ltd [1954] 2 QB 182 (CA) at 197.

63 Marcic $v$ Thames Water Utilities Ltd, above n 36, at [85] (reversed on appeal on different points of law); Michael Jones (ed) Clerk \& Lindsell on Torts (21st ed, Sweet \& Maxwell, London, 2014) at [20-34]. Compare Hiscox Syndicates Ltd v The Pinnacle Ltd [2008] EWHC 145 at [30], a case involving amenity 
Hoffmann in Transco nor the Court of Appeal in Northumbrian Water made any reference to this principle. A reversed burden of proof would make nuisance a more claimant-friendly option, by offering extra protection for interests in land, and by holding users of land to a stricter standard than ordinary defendants.

Secondly, nuisance tends to be associated with a more flexible approach to causation. While negligence does not usually impose liability for mere omissions, courts have been willing to hold defendants liable for failing to abate hazards on their land. ${ }^{64}$ For example, a defendant may be liable if a tree on their land catches fire through natural causes and, because the defendant does not do anything to stop it, the fire spreads and causes damage to their neighbour's land. Yet negligence has always formed an integral part of such claims, to the extent that it is unclear whether they are properly classified as claims in negligence or nuisance. ${ }^{65}$ A defendant will not be liable unless they knew, or should have known, of the nuisance and failed to take reasonable steps to abate it. It is probably true that "the question of categorisation is academic". ${ }^{66}$ But plaintiffs may still wish to plead negligence and nuisance together.

Finally, a plaintiff may choose nuisance over negligence due to subtle differences in the extent or availability of remedies. While the calculation of damages for physical damage would be the same, a nuisance action would also enable recovery for an associated loss of amenity value. For example, if a sewage spill ruins the plaintiff's crop and produces excessive smells, the plaintiff will be able to claim damages in nuisance - but not in negligence - for the loss of amenity resulting from the smell. Nuisance may also prove the better choice where the plaintiff is concerned with future or ongoing damage to their land. As a matter of principle, it is difficult to see why injunctive relief would not be available in negligence if it is available in nuisance. ${ }^{67}$ But while injunctions are a fixture of the law of nuisance, their role in negligence appears to be unsettled. ${ }^{68}$

interference. See also the defence of ignorance in Michael Jones (ed) Clerk \& Lindsell on Torts (21st ed, Sweet \& Maxwell, London, 2014) at [20-99].

64 Sedleigh-Denfield, above n 36; Goldman v Hargrave, above n 36; Leakey v National Trust for Places of Historic Interest or Natural Beauty [1980] QB 485 (CA); and generally Basil Markesinis "Negligence, nuisance and affirmative duties of action" (1989) 105 LQR 104

65 Goldman v Hargrave, above n 36, at 461 per Lord Wilberforce: "The present case is one where liability, if it exists, rests upon negligence and nothing else; whether it falls within or overlaps the boundaries of nuisance is a question of classification which need not here be resolved."

66 Marcic v Thames Water Utilities Ltd, above n 36, at [55].

67 See generally Murphy "Rethinking Injunctions in Tort Law", above n 35.

68 Miller v Jackson [1977] QB 966 (CA) at 980 per Lord Denning MR. See also Murphy, above n 35. 


\section{CONCLUSION}

The Court of Appeal's reasoning in Northumbrian Water does not properly reflect the troubled history of foreseeability of harm as an element of nuisance. Lord Wilberforce in Goldman noted that the tort of nuisance was "uncertain in its boundary" and that it "may comprise a wide variety of situations, in some of which negligence plays no part, in others of which it is decisive". ${ }^{69}$ But if it is accepted that liability in nuisance depends on reasonable foreseeability of harm, then the boundaries of liability are, finally, clearly drawn. The element of foreseeability goes hand in hand with a standard of care, measuring the defendant's use of land against the conduct of a reasonable person. It is not enough that the defendant has caused the harm. Nuisance is a tort about wrongful conduct.

This conceptualisation is consistent with the rule in Rylands $v$ Fletcher, which, unlike an ordinary action in private nuisance, is extremely difficult to satisfy for the very reason that it imposes strict liability. It is also consistent with the principles underlying the tort of nuisance more generally. In cases that do not involve physical damage, courts have to weigh "the right of the occupier to do what he likes with his own" with "the right of his neighbour not to be interfered with" to determine whether there has been an unreasonable interference with the plaintiff's use or enjoyment of land. ${ }^{70}$ Ultimately, the court must find that the defendant wrongly prioritised their interests over those of the plaintiff, and that they should not have used their land in the offending manner.

The real value of nuisance, therefore, lies in its ability to resolve competing interests in the use of land. It provides an answer to a defendant's claim that they are entitled to use their land how they like even if this disturbs their neighbour. Negligence is of no assistance in such cases because it does not provide a remedy for interferences with the amenity value of land. The flipside is that nuisance is of only limited value in cases of physical damage. Here, there is no need to resolve competing interests in the use of land, because physical damage is never acceptable, and nuisance and negligence usually overlap. The overall effect of discarding the principle of strict liability is to reduce the scope of nuisance.

69 Goldman v Hargrave, above n 36, at 461.

70 Sedleigh-Denfield, above n 36, at 903 per Lord Wright. 